\title{
The Reformulation of Restitution Concept in Juvenile Cases (A Comparative Study with Philippines and Thailand)
}

\author{
I Wayan Putu Sucana Aryana* \\ DOI: https://doi.org/10.22304/pjih.v7n3.a5
}

Submitted: August 07, 2020 | Accepted: December 10, 2020

\begin{abstract}
The principles of international law mandate diversion as a model for solving juvenile cases. The diversion model as a resolution model in Indonesia, Philippines, and Thailand is rooted in the traditional culture and local wisdom of the people. Diversion agreement can take form of restitution. This study discusses three issues: (1) diversion in juvenile criminal justice system, (2) restitution in diversion, and (3) comparison of restitution in the Philippines and Thailand. This study employs normative legal approach, which examines the ambiguity of norms of restitution forms. Currently, restitution is interpreted merely as reimbursement for victim. This study collected primary and secondary legal materials collected through literature study. This study employed statutory, legal concept, and comparative law approaches. The focus was on the Philippines and Thailand contexts. The analysis was conducted qualitatively. Diversion is a specialty in the juvenile criminal justice system in which criminal cases committed by children are resolved by deliberation. The result of the diversion agreement can be in the form of restitution as agreed in the deliberation. The Law Number 11 of 2012 on the Juvenile Criminal Justice System recognizes form of restitution. The form is money. It is different from the Philippines and Thailand that formulating a form of restitution in the form of services provided by the perpetrator and/or his family to the victim and/or his family. This form of restitution is based on social realities in which the economic condition of the perpetrator's family makes it impossible to pay restitution in the form of money. The restitution of work services can be a material for reformulation in the dimension of ius constituendum in Indonesia.
\end{abstract}

Keywords: diversion, juvenile, restitution.

\section{Reformulasi Konsep Ganti Kerugian pada Perkara Anak (Studi Perbandingan dengan Philipina dan Thailand)}

\begin{abstract}
Abstrak
Prinsip hukum internasional mengamanatkan model penyelesaian perkara anak melalui diversi. Model penyelesaian perkara secara diversi, baik di Indonesia, Philipina maupun Thailand berakar dari budaya tradisional dan kearifan lokal masyarakat setempat. Hasil kesepakatan diversi dapat berupa ganti rugi. Dalam penelitian ini akan dibahas mengenai tiga permasalahan yakni diversi dalam sistem peradilan pidana anak, ganti rugi dalam
\end{abstract}

PADJADJARAN Journal of Law Volume 7 Number 3 Year 2020 [ISSN 2460-1543] [e-ISSN 2442-9325]

Lecturer of the Faculty of Law, Universitas Ngurah Rai, I. Kampus Ngurah Rai No.30, Penatih, Kec. Denpasar Timur, Kota Denpasar, Bali 80238, Dr., S.H., M.H. (Universitas Ngurah Rai), sucanaaryana67@gmail.com 
diversi, dan perbandingan ganti rugi di Philipina dan Thailand. Penelitian ini merupakan penelitian normatif yang mengkaji mengenai kekaburan norma mengenai bentuk ganti rugi. Saat ini, ganti rugi hanya diintepretasikan sebagai pembayaran sejumlah uang bagi korban. Bahan hukum dalam penelitian ini adalah bahan hukum primer dan bahan hukum sekunder yang dikumpulkan melalui studi kepustakaan. Penelitian ini dilakukan dengan pendekatan perundang-undangan, pendekatan konsep hukum dan pendekatan perbandingan hukum, yakni dengan Filipina dan Thailand. Analisis penelitian dilakukan secara kualitatif. Diversi merupakan kekhususan dalam sistem peradilan pidana anak dimana perkara pidana yang dilakukan oleh anak diselesaikan secara musyawarah. Hasil kesepakatan diversi dapat berupa ganti kerugian yang disepakati dalam musyawarah tersebut. Bentuk ganti rugi yang dikenal dalam Undang-undang Nomor 11 Tahun 2012 tentang Sistem Peradilan Pidana Anak adalah adalah dalam bentuk pembayaran berupa uang. Berbeda dengan Philipina dan Thailand yang merumuskan bentuk ganti kerugian berupa pelayanan yang diberikan oleh pelaku dan/atau keluarganya kepada korban dan/atau keluarganya. Bentuk ganti rugi tersebut didasari oleh kenyataan sosial dimana kondisi ekonomi dari keluarga pelaku tidak memungkinkan untuk membayar ganti rugi dalam bentuk uang. Bentuk ganti rugi berupa pelayanan kerja ini dapat menjadi bahan reformulasi dalam dimensi ius constituendum di Indonesia.

Kata kunci: anak, diversi, ganti rugi.

\section{A. Introduction}

Child protection covers all activities to guarantee and to protect children and their rights so that they can live, grow, develop, and participate optimally compliant with human dignity and protection from violence and discrimination. Child protection is an important substance of criminal justice system because of children's special needs. The specificity of the juvenile justice system is stated by the United Nations Standard Minimum Rules for the Administration of Juvenile Justice, also known as "The Beijing Rules". It was adopted by the General Assembly Resolution number 40/33 of 29 November 1985. Provision 1.4 of The Beijing Rules states the following.

"Juvenile justice shall be conceived as an integral part of the national development process of each country, within a comprehensive framework of social justice for all juveniles, thus, at the same time, contributing to the protection of the young and the maintenance of $a$ peaceful order in society". ${ }^{1}$

Compared to adult, children require a different pattern of case handling in the criminal justice system. Settlement of juvenile criminal cases can be carried out through processes inside and outside court. The settlement of juvenile criminal cases through a court process, which may lead to conviction, is used as a last resort. Therefore, out-of-court settlement is the priority as long as crime act committed by child is not a serious one. Out-of-court settlement is also known as

1 Provision 1.4 of the Beijing Rules. 
restorative justice, which is the most recommended form of diversion adjacent to children who face law problem because the concept of restorative justice involves various parties in problem solving. ${ }^{2}$

Deprivation of liberty such as imprisonment and detention are the last resort in handling juvenile cases. Juvenile justice system prioritizes diversion with a restorative justice approach. According to the history of criminal law, the word "diversion" was first put forward in a report on the implementation of juvenile justice submitted by the President of the Crime Commission of Australia in $1960 .^{3}$ In fact, the term diversion had been used before 1960 through the establishment of children's courts. It was before the $19^{\text {th }}$ century, namely diversion from the formal criminal justice system and the formalization of the police to carry out police cautioning. The practice has taken place in Australian, to be precise, the state of Victoria in 1959 and followed by Queensland in 1963. ${ }^{4}$

Settlement of cases through diversion is a culture of Indonesian society, in which problem solving is carried out based on deliberation to reach consensus. The Law Number 11 of 2012 on the Juvenile Criminal Justice System legitimizes diversion in child cases in Indonesia. Article 1 paragraph 7 states that diversion is the transfer of settlement of children's cases from the criminal justice process to the process outside the criminal court. ${ }^{5}$

The restorative justice approach helps criminals to avoid other crimes in the future. ${ }^{6}$ Restorative juvenile justice model departs from the assumption that the response or reaction to the child's delinquent behavior will not be effective without the cooperation and involvement of victim, perpetrator, and the community. The principle that underlies restorative justice model is that justice is best served, if each party receives fair and balanced attention, is actively involved in the judicial process, and benefits adequately from their interaction with the juvenile justice system. ${ }^{7}$

The implementation of diversion with a restorative justice approach can be disserted with various programs. For instances, it may include payment of damages from perpetrator to victim. Part I.2. of the Basic principles on the use of restorative

2 Pangestika Rizki Utami, Konsep Diversi dan Restorative Justice Sebagai Pergeseran Tanggung Jawab Pidana Pada Sistem Peradilan Pidana Anak, Purwokerto: IAIN Purwokerto, 2018, p. 103.

$3 \quad$ Folk, Kenneht, "Early Intervention: Diversion and Youth Conferencing, A National Reviewof Current Approach to Diverting Juvenile from The Criminal Justice System", Australia: Government Attorney-General's Departement of Commonwealth of Australia, 2003, p. 1.

4 Chlmlinger, D., "Police Action and the Prevention of Juvenile Deliquency", in A. Borowski and JM. Murray, Juvenile Delinquency in Australia, New South Wales: Methuen Australia, 1985, pp. 290-302.

5 See Article 1 Paragraph 7 of the Law Number 11 of 2012 on the Juvenile Criminal Justice System.

$6 \quad$ Friendly Juin Umpele, "Analisis Yuridis Pertimbangan Hakim dalam Penjatuhan Pidana Terhadap Anak Sebagai Pelaku Tindak Pidana Narkoba", Lex Crimen, Vol. 8, No. 2, 2019, p. 183.

$7 \quad$ Nurini Aprilianda, "Laporan Akhir Pengkajian Hukum Tentang Model Pembinaan Anak Berbasis Pendidikan Layak Anak Dalam Sistem Pemasyarakatan”, Pusat Penelitian Dan Pengembangan Sistem Hukum Nasional Badan Pembinaan Hukum Nasional Kementerian Hukum Dan Hak Asasi Manusia RI, 2014. 
justice programs in criminal matters, ECOSOC Res. 2000/14, U.N. Doc. E/2000/INF/2/Add.2 at 35 (2000) states the following.

"Restorative outcome" means an agreement reached as the result of a restorative process. Examples of restorative outcomes include restitution, community service and any other programme or response designed to accomplish reparation of the victim and community, and reintegration of the victim and/or the offender". 8

One of the requirements that must be fulfilled is that the chosen justice must be based on an agreement that has been established with the parties to produce justice as fairness. ${ }^{9}$ The agreement in the diversion of the juvenile criminal justice system can be in the form of restitution. Restitution for damages is an obligation imposed on people who have acted against the law and caused harm to others because of their mistakes. ${ }^{10}$ Article 11a of the Law Number 11 of 2012 on the Criminal Justice System for Children affirms that the results of diversion agreement can take some forms. One of the forms is reconciliation with or without restitution.

Article 10 paragraph (2) of the Law Number 11 of 2012 on the Juvenile Criminal Justice System reads as follows.

"Diversion agreement as referred to in paragraph (1) is carried out by investigators on the recommendation of the Community Advisor, which can take the following forms: refund of losses in the event of a victim". ${ }^{11}$

Article 8 paragraph (1) of the Government Regulation number 65 of 2015 on the Guidelines for the Implementation of Diversion and Handling of Children Aged Under 12 (Twelve) Years Old states as follows.

"In the case of Diversion agreements as referred to in Article 6 paragraph (3) and Article 7 paragraph 4) requires the payment of restitution or refund in its original condition, the Diversion agreement is carried out within the agreed period of time in the Diversion, but may not exceed 3 (three) months". ${ }^{12}$

Based on the provision, the legislators interpret the restitution as the reimbursement.

Part 1.2. of the ECOSOC Res. 2000/14, U.N. Doc. E/2000/INF/2/Add.2 at 35 (2000).

O.C. Kaligis, Perlindungan Hukum Atas Hak Asasi Tersangka Terdakwa dan Terpidana, Bandung: Alumni, 2006, p. 22.

Sudarto, Kapita Selekta Hukum Pidana, Bandung: Penerbit Alumni, 1981, p.133.

Article 10 Paragraph (2) of the Law Number 11 of 2012 on the Juvenile Criminal Justice System.

Article 8 Paragraph (1) of the Government Regulation Number 65 of 2015 on the Guidelines for the Implementation of Diversion and Handling of Children Aged Under 12 (Twelve) Years Old. 
The laws and regulations in Indonesia do not standardize forms of restitution other than money. However, in addition to money, there are still other forms of restitution such as perpetrator and/or perpetrator's family doing social work for victim and/or victim's family. The interpretation of restitution in the form of money tends to cause offenders who come from underprivileged families have less opportunity to settle cases in restorative justice. This condition creates obstacles to excess justice for children whose families are unable to provide the restitution to victims.

This study is normative juridical, which examines the ambiguity of norms of restitution forms. Law enforcer comprehends restitution as a sum of money given by perpetrator and/or perpetrator's family to victim. The legal material of the study is primary legal material consisting of the Law number 11 of 2012 on Juvenile Criminal Justice System and the Government Regulation number 43 of 2017 on the Implementation of Restitution for Children Who Are Victims of Crime. Secondary legal materials consist of relevant books, journals, and electronic articles. The legal materials were collected through literature study. The approach of the study is statutory approach, legal, and comparative law approaches. Legal comparisons are made by comparing the Indonesian provisions on restitution with the ones in the Philippines and Thailand. The Philippines and Thailand were made focuses based on the consideration that both states have legal culture similar to Indonesia. The two states are in the same legal tradition as Indonesia, the civil law legal tradition. This study is a qualitative study.

\section{B. Diversion as a Specialty in the Juvenile Criminal Justice System}

Most children cannot protect themselves from various kinds of actions that cause mental, physical, and social harms. In various fields of life and the livelihoods, children must be protected. Various situations and conditions, especially the implementation of the Juvenile Criminal Court, are strange to them. ${ }^{13}$ Children have a special position before the law, and it cannot be separated from several principles. First, children with all inherent limitations are not able to protect their own rights. Therefore, parents, society and the state must participate in protecting their rights. Second, the principle of the best interests of children requires them to be the main priority. Third, the principle of life circle approach demands the protection of children must be started early and sustainably. Fourth, it is crosssectoral principles that the fate of children is very dependent, directly, and indirectly, on various macro and micro factors. ${ }^{14}$

The criminal law must be able to protect the interests and rights of children, not only in the present but also in the future. Child protection is implemented

\footnotetext{
13 Hamka Muchtar, and Benny Diktus Yusman, "Implementasi Restorative Justice dalam Penyelesaian Perkara Delinkuensi", Tadulako Master Law Journal, Vol. 4, No. 2, 2020, p. 147.

14 Muhammad Joni, Aspek Hukum Perlindungan Anak Dalam Perspektif Konvensi Hak Anak, Bandung: Citra Aditya Bakti, 1999, p. 106.
} 
based on the principles of non-discrimination, namely respecting and guaranteeing the rights of every child in the Indonesian jurisdiction. They must be without discrimination in any form, regardless of race, color, sex, language, religion, political or other views, national, ethnic, social origin, assets, disabilities, birth or other status of child or of child's parents or legal guardian. The principle of child protection also places children in the context of their rights to survive and develop. The state must guarantee the survival and the development of children as much as possible. All actions involving children carried out by government or private institutions must place the best interests of children as the main considerations. They must increase the opportunities for children to participate in expressing opinions. ${ }^{15}$

Children's rights have been included in various international legal instruments. The instruments are mostly related to human rights. The Universal Declaration of Human Rights Article 25 paragraph (2) states as follows.

"Motherhood and childhood are entitled to special care and assistance.

All children, whether born in or out of wedlock, shall enjoy the same social protection". ${ }^{16}$

Internationally, child protection is regulated in the Convention on the Rights of the Child that is adopted and opened for signature, ratification, and accession based on the General Assembly Resolution number 44/25 of November 20, 1989. The resolution is valid since September 2, 1990, in accordance with Article 49. The emergence of international agreement on the protection is based on the awareness to prepare children to live and to interact within society.

The Convention on the Rights of the Child is an evidence of a new vision and paradigm on the protection of child. It emphasizes that fostering children's welfare includes providing opportunities to develop their rights. The implementation is not only the responsibility of parents, family, nation, and state but also requires international cooperation. ${ }^{17}$

Special treatment for children in the criminal justice system is a global commitment. It is outlined in Point 6.1 of the Beijing Rules on the Scope of discretion. The point states,

"In view of the varying special needs of juveniles as well as the variety of measures available, appropriate scope for discretion shall be allowed at all stages of proceedings and at the different levels of

15 Direktorat Bina Kesejahteraan Anak, Keluarga dan Lanjut Usia, "Pedoman Perlindungan Anak", Jakarta: Direktorat Bina Kesejahteraan Anak, Keluarga dan Lanjut Usia, 2016, p. 16.

Article 25 Paragraph (2) of the Universal Declaration of Human Rights.

17 Majda El Muhtaj, Dimensi-dimensi HAM Mengurai Hak Ekonomi, Sosial dan Budaya, Jakarta: Raja Grafindo Persada, 2009, p. 227. 
juvenile justice administration, including investigation, prosecution, adjudication and the follow-up of dispositions". ${ }^{18}$

In addition, ECOSOC Res. 2000/14, U.N. Doc. E/2000/INF/2/Add.2 at 35 (2000), part number 6 , states that, "restorative justice programs should be generally available at all stages of the criminal justice process" ${ }^{19}$

Number 7 states as follows.

"Restorative processes should be used only with the free and voluntary consent of the parties. The parties should be able to withdraw such consent at any time during the process. Agreements should be arrived at voluntarily by the parties and contain only reasonable and proportionate obligations". ${ }^{20}$

This provision provides a large space for solving children's cases through diversion. In various international documents and meetings, the need for legal protection for children can cover various aspects. They are (a) protection of children's rights and freedoms; (b) protection of children in the judicial process; (c) protection of the welfare of children (in the family, education, and social environment); (d) protection of children in matters of detention and deprivation of liberty; (e) protection of children from all forms of exploitation (slavery, child trafficking, prostitution, pornography, drug trafficking/abuse, exploiting children in committing crimes, etc.); (f) protection of street children; (g) protection of children from the consequences of war/armed conflict; and (h) child protection against acts of violence. $^{21}$

Diversion is a settlement method of juvenile cases. It shifts criminal justice processes to non-criminal justice processes. It is emerged and developed as a reaction to dissatisfaction on previous juvenile criminal justice system, which focused on state and perpetrators, without the involvement of all conflicting parties and the community. This is different from restorative justice, which involves victims and community actors in the problem solving. ${ }^{22}$ Settlement of cases through deliberation aims to achieve harmony within society. It does not intend to make situation worse and to maintain peace atmosphere. The concept of diversion proposes to attain reconciliation between perpetrator and victim by providing restitution or by apologizing. There should be no more conflict after the diversion and the perpetrator will not repeat the evil deeds and feel regret. Diversion program can be in the form of warnings, skill developments, guidance, or

\footnotetext{
Abintoro, Pembaruan Sistem Peradilan Pidana Anak, Yogyakarta: Laksbang Grafika, 2012, p. 155. Part Number 6 of the ECOSOC Res. 2000/14, U.N. Doc. E/2000/INF/2/Add.2 at 35 (2000). Part Number 7 of the ECOSOC Res. 2000/14, U.N. Doc. E/2000/INF/2/Add.2 at 35 (2000). Barda Nawawi Arief, Beberapa Aspek Kebijakan Penegakan dan Pengembangan Hukum Pidana, Bandung: Citra Aditya Bakti, 1998, p. 156.

22 Lilik Mulyadi, Wajah Sistem Peradilan Pidana Anak Indonesia, Bandung: PT Alumni, 2014, p. 156.
} 
counseling. The diversion process and program are carried out in a pleasant manner.

The idea of diversion idea aims to avoid detention, label of criminal, and to improve the perpetrator's life skills, the perpetrator responsibility, prevention recurrence of criminal acts, necessary informal interventions for both victims and perpetrators. Diversion program can prevent children from involvement in court system processes. Further steps in this program may keep children away from the negative impacts and implications of the judicial process. ${ }^{23}$ Out-of-court resolution as an alternative to the criminal justice system is necessary for several reasons as follows.

1. It is expected that it can reduce the buildup of cases.

2. It is a dispute resolution process faster, cheaper, and simpler.

3. It can provide the widest possible access to the disputing parties to obtain justice.

4. It can strengthen and maximize the function of court institution in dispute resolution, not limited to the process of imposing punishment. ${ }^{24}$

Settlement of cases through diversion provides many benefits, namely allow perpetrator (1) to keep their jobs; (2) to contribute to society; (3) to continue to support and be supported by family; (4) to avoid the unnecessary expense, trauma, and bad influence of jail prison when what they need most is substance or mental health treatment; (5) to address their behavior without the stigma of a criminal conviction; (6) to clear their records after the program; (7) to reduce the expense and negative effects of prison overcrowding; and (8) to acknowledge the shift in public sentiment away from harsh penalties for non-violent crimes, mental illness, and drug offenses. ${ }^{25}$

The rights and legal protection for children are approaches to protect Indonesian children. It is expected that the protection of children's rights can be carried out consistently, orderly, and responsibly. It is necessary to have legal regulations that are in line with the development of Indonesian people based on Pancasila and the 1945 Constitution. ${ }^{26}$ Indonesia is a constitutional state. Therefore, all aspects of people's life shall be based on law. In the implementation, the state apparatus can enforce to create a peaceful, orderly, and just society. The

\footnotetext{
23 Apong Herlina (et.al), Perlindungan Terhadap Anak yang Berhadapan dengan Hukum, Jakarta: POLRI UNICEF, 2004, p. 330.

24 Ds Dewi and Fatahillah A. Syukur, Mediasi Penal, Penerapan Restoratif Justice di Pengadilan Anak Indonesia, Depok: Indie Publishing, 2011, p. 8.

25 Edwina Rogers, Diversion Programs in America's Criminal Justice System: A Report by the Center for Prison Reform, Washington: The Center for Prison Reform, 2015, p. 3.

26 Wagiati Sutedjo, Hukum Pidana Anak, Bandung: PT Refika Aditama, 2010, p. 67.
} 
law demands people to do the real thing to be bound by the legal norms within the state. $^{27}$

Pancasila and the 1945 Constitution are the sources of the Law number 11 of 2012 on the Juvenile Criminal Justice System. Article 7 of the Law states as follows:

"(1) At the level of investigation, prosecution, and examination of a child's case in a district court, diversion is obligatory.

(2) Diversion as referred to in paragraph (1) shall be implemented in the event of a criminal act committed:

a. is threatened with imprisonment of less than 7 (seven) years; and

b. is not a repetition of a criminal act". ${ }^{28}$

The Law requires legal officers to seek diversion in the juvenile criminal justice system, to be precise to transfer of settlement of juvenile cases from the criminal justice process to processes outside the criminal court. Children in conflict with the law must be faced to be handled and continued with restorative justice. The roots of the philosophy of restorative justice are the conception of justice for all, based on deliberation in order to restore the state after the occurrence of legal events humanely. Theoretically, the juvenile justice system in Indonesia is obliged to prioritize the best interests of the children and strive to reduce the settlement of juvenile cases in criminal courts. Punishment is only carried out as a last resort and in a short time. ${ }^{29}$

Diversion is not carried out by criminal means, but rather by reconciling the victim with the perpetrator and his family, as well as law enforcers or other relevant matters. The parties together seek a fair solution by emphasizing restoration to the original state, and not retaliation. The diversion process is carried out through deliberations involving children and parents/guardians, victims and parents/guardians, community assistants, and professional social workers based on a restorative justice approach. In addition, deliberation can also involve social welfare workers and / or elements of society. Victims and their families must be active in the diversion process so that the recovery process can be achieved in accordance with restorative justice. The results of a diversion agreement may include, among others, reconciliation with or without restitution; returned to the parent/guardian; participation in education or training in educational institutions for a maximum of three months; or community service.

The problem of solving juvenile cases cannot be separated from the efforts to handle children crime. It is an effort to eradicate crimes committed by children. However, there are still weaknesses in the implementation of diversion. Diversion

\footnotetext{
27 Dahlan Thaib, Jazim Hamidi and Ni'matul Huda, Teori dan Hukum Konstitusi, Jakarta: Raja Grafindo Persada, 2009, p. 76.

28 Article 7 of the Law Number 11 of 2012 on the Juvenile Criminal Justice System.

29 Rr Putri A Priamsari, "Mencari Hukum yang Berkeadilan bagi Anak Melalui Diversi”, Jurnal Law Reform, Vol. 14, No. 2, 2018, p. 225.
} 
as an effort to achieve restorative justice only reaches repressive efforts that focus on efforts to overcome crime after the crime has occurred and does not reach preventive efforts before the crime occurs. Bramita and Cahyaningtyas find several obstacles in the implementation of diversion as follows.

1. Many law officers/enforcers do not know and understand restorative justice and diversion. Therefore, there are various perceptions in the implementation.

2. Diversion is understood as restitution (the cost of restitution for items stolen, damaged, medical expenses, customary costs, etc.) so that no agreement is reached because the nominal figures are not in accordance with the wishes of the victim/family or child/family.

3. The behavior or level of desire of law enforcers who tend not to achieve the goal of diversion in which they are partial to either party (victim/perpetrator) and are unable to act as a mediator or facilitator. ${ }^{30}$

In the context of law enforcement, the restitution agreement is the key to achieving peace from the parties, namely children in conflict with the law and victims. Therefore, the ability to pay restitution to victims will determine the course of cases of children in conflict with the law.

\section{Restitution in the Juvenile Criminal Justice System}

A fair trial is a demand and a basic principle of universal human rights and a characteristic of a democratic state. In the trial process of criminal cases, victim occupies an important position to reveal the crime event but, so far, lawmakers and enforcers mostly focus on perpetrator of crime acts. The focus on victim is often neglected because, to date, victim in the criminal justice process, especially at the investigation stage, seems to receive less attention and lack of legal protection. A victim has rights like any other human being, as guaranteed in human rights conventions and legally protected by agreement. ${ }^{31}$ The diversion process must pay attention to the interests of victim; children's welfare and responsibility; avoidance of negative stigma; avoidance of retaliation; community harmony; and propriety, decency, and public order.

Diversion is a criminal policy in solving juvenile cases. Dzhansarayeva, Bissengali, Bazilova, Akbolatova, and Bissenova formulates that criminal policy should be interpreted as:

1. State policy (doctrine) of anti-criminal fight expressed in associated directives (laws, Decrees of President, governmental regulations);

2. Specific type of social activity aimed at active countermeasures to criminality and other offenses of law;

30 Fifid Bramita and Irma Cahyaningtyas, "Children Hearing System sebagai Ide Pembaharuan Sistem Peradilan Pidana Anak di Indonesia", Jurnal Magister Hukum Udayana (Udayana Master Law Journal), Vol. 7, No. 4, 2018, p. 533.

31 Ansori, "Perlindungan Hukum Terhadap Korban Perkosaan dalam Peradilan Pidana di Indonesia”, Disertasi, Universitas Brawijaya, Malang, 2011, p. 1. 
3. Scientific theory and synthesis of relevant political, sociological, and legal knowledge. Therefore, in the determination of its matter the criminal policy relies on the integrative characteristics of state social policy, provisions of management theory and sciences of criminal law cycle and the achievements of sociology and politology. ${ }^{32}$

Restorative Justice is a way to impose sanctions on lawbreaker by giving the victim rights to participate actively in the judicial process. Indicators of sanctions in the application of restorative justice can be seen from whether the victim has been restored, the victim's satisfaction, the amount of restitution, the perpetrator's awareness of his actions, the number of repair agreements made, the quality of work services, and the entire process. ${ }^{33}$ In line with the increasingly effective protection of the law on the public interest in peace and order, and the belief that "retaliation" is a deterrent, the payment for restitution will shift its position. Initially, it is a "privilege"; then it becomes an "obligation".

The legal definition of restitution can be seen in the Government Regulation number 43 of 2017 on the Implementation of Restitution for Children Who Are Victims of Crime. Article 1 paragraph 1 reads as follows.

"Restitution is the payment of compensation charged to the perpetrator based on a court decision which is legally binding for material and/or immaterial losses suffered by the victim or his heirs". 34

The measure of "restitution" is no longer based on the retaliation that must be "paid", but from the point of view of the loss or suffering caused by the actions of the perpetrator. ${ }^{35}$

The agreement obtained from the diversion process contains an element of restitution that must be implemented by the parties. The law does not explicitly explain that the restitution process is diversion. It is just that the form of a diversion agreement is explained. Law enforcers in the implementation of diversion must consider this. ${ }^{36}$ The restitution by the perpetrator is not only in the form of material but it also depends on the loss suffered by the victim. The restitution can be in the form of money, medical expenses, and in the form of goods covering the

32 Dzhansarayeva (et.al), "Problems of Formation of the Concept of Criminal Policy of State in the Theory of Criminal Law", Middle-East Journal of Scientific Research, Vol. 14, No. 4, 2013, p. 510.

33 Fetri AR. Tarigan, "Upaya Diversi Bagi Anak dalam Proses Peradilan", Lex Crimen Vol. 4, No. 5, 2015, p. 110.

34 Article 1 Paragraph (1) of the Government Regulation Number 43 of 2017 on the Implementation of Restitution for Children Who Are Victims of Crime.

35 Sekhroni, "Criminal Liability dan Diversi Terhadap Tindak Pidana Anak dalam Sistem Peradilan Anak di Indonesia", Unifikasi: Jurnal IImu Hukum, Vol. 3, No. 1, 2016, p. 49.

36 Rina Nurhaliza, Herry Liyus, and Dheny Wahyudi, "Pelaksanaan Kesepakatan Diversi pada Tingkat Penyidikan dalam Sistem Peradilan Anak", Pampas: Journal of Criminal Law, Vol. 1, No. 1, 2020, p. 113. 
victim's losses. It depends on the agreement between the victim and the perpetrator. $^{37}$

In the history of Indonesian law, the concept of restitution is found in various books of Law. One of which is from the Majapahit era, which is what is called religious legislation. There was a principal punishment in the form of restitution or panglisyawa or patukusyawa. The legislation from Majapahit shows a relationship between the perpetrator and the victim as follows.

Article 56:

"If a thief asks for live, then he must redeem eight ropes of release, pay a fine of four laksa to the ruling king, pay damages (panglisyawa) to the person who is a victim by returning all property he/she has taken twice". ${ }^{38}$

Article 242:

"Whoever rides a cart, horse, or any vehicle, if he/she violates or steps on a person to death, the sanction is fined for two hundred by the ruling king, plus restitution money (pamidara) of eight ropes to the offended person, or to the dead person's relatives". ${ }^{39}$

\section{Article 19:}

"Whoever kills an innocent woman must pay twice to the victim and be charged four times restitution (patukusyawa)". ${ }^{40}$

In fact, restitution has long been known in civil law. The penalty for damages is included in "the law of tort", in which the injured party (victim of a crime) must file a claim in the form of money or something economically. In this case, there is an expropriation of everything, which is restitution for victims of crime and the state. Victim and crime involve in a civil relationship. ${ }^{41}$ The provisions regarding the liability for restitution are regulated in Article 1365 of the Civil Code. It states that every act of violating the law, which results in loss to another person, obliges the person, because of his fault to cause loss, to compensate for the loss party. Various states also apply classification regarding restitution as follows.

1. Restitution is considered civil in nature and is given in civil procedures.

2. Restitution is civil in nature but provided for a criminal procedure.

3. Restitution is civil in nature but is tied into a criminal nature and given to criminal procedures.

Rina Nurhaliza, Herry Liyus, and Dheny Wahyudi, op.cit., p. 117.

Article 56 of the Principal Punishment in the Form of Restitution or Panglisyawa or Patukusyawa.

Article 242 of the Principal Punishment in the Form of Restitution or Panglisyawa or Patukusyawa.

Slamet Muljana, Perundang-Undangan Majapahit, Jakarta: Bhratara, 1967, p. 29.

Romli Atmasasmita, Teori \& Kapita Selekta Kriminolog, Bandung: PT. Eresco, 1992, pp. 2-3. 
4. Restitution is civil in nature and is given in criminal procedures, but payment is the responsibility of the state.

5. Restitution is neutral in nature and given in special procedures as well. ${ }^{42}$

There are three categories of restitution for an unlawful act. The first is nominal of restitution. If there is a serious illegal act, such as an act that contains an intentional element but does not cause real harm to the victim, then the victim can be given a certain amount of money according to the sense of justice without calculating the amount of the loss. The second is compensatory damages. It is restitution in which a payment to the victim for and equal to the loss that has been experienced by the victim from an illegal act. Therefore, this restitution is also known as actual restitution. For example, restitution for all costs incurred by the victim of loss of profit/salary, illness, and suffering, including mental suffering such as stress, shame, falling of good name, etc. The third is punitive damages. It is a restitution with an amount of the actual loss. The amount of restitution is intended as a punishment for the perpetrator. This punitive restitution is appropriate to apply to the severe torture of a person. ${ }^{43}$

Article 1 paragraph 4 of Law number 11 of 2012 on the Criminal Justice System for Children reads as follows.

"Children who become victims of criminal acts, hereinafter referred to as Child Victims, are children under the age of 18 (eighteen) who experience physical, mental, and/or suffering economic losses caused by criminal acts".

Based on the formulation of these provisions, the losses mean material or nonmaterial losses. The restitution in the diversion agreement includes nominal restitution and compensatory damages. The implementation of restitution that is often applied in criminal law can be seen from traffic violations that cause losses to victims. The perpetrator usually pays for medical care, reimbursement for repair of damaged vehicles, restitution for the victim's family, etc.

Various provisions and implementations of restitution in the Indonesian legal system only led to money payment from the perpetrator to the victim. As a result, children who are from underprivileged families and are unable to fulfill restitution to victims will lose the opportunity to settle the case through diversion. On the other hand, children who are from well-off families will easily pay restitution to the victim so that the criminal case goes straight closed.

2 Moch. Faisal, Hukum Acara Pidana dalam Teori dan Praktek, Bandung: Manda Maju, 2001, p. 160.

43 Miszuarty Putri, "Pelaksanaan Restitusi Bagi Anak Yang Menjadi Korban Tindak Pidana Sebagai Bentuk Pembaruan Hukum Pidana Berdasarkan Peraturan Pemerintah Nomor 43 Tahun 2017", Soumatera Law Review, Vol. 2, No. 1, 2019, p. 117.

44 Article 1 Paragraph (4) of Law Number 11 of 2012 on the Criminal Justice System for Children. 


\section{Comparison with the Philippines and Thailand}

The settlement of criminal cases outside of court and the concept of restitution in criminal law are the answers to the intention to simplify the criminal court process, which so far seems rigid. Frank states that law must have the character of fluidity and pliancy because legal problems that are constantly developed and are unpredicted require the law to always adapt to social, industrial, technological, and political realities that continue to constantly change. Therefore, law must be impermanent, experimental, and cannot be calculated with certainty. ${ }^{45}$

Diversion provisions in the juvenile justice system are not only developed in Indonesia but also in other states, including in neighboring countries like the Philippines and Thailand. The Philippines regulates diversion in the Republic Act No. 9344 or known as an Act Establishing a Comprehensive Juvenile Justice and Welfare System, Creating the Juvenile Justice and Welfare Council Under the Department of Justice, Appropriating Funds Therefore and for Other Purposes. Sec. 4 reads as follows. ${ }^{46}$

"(i) Diversion refers to an alternative, child-appropriate process of determining the responsibility and treatment of a child in conflict with the law on the basis of his/her social, cultural, economic, psychological or educational background without resorting to formal court proceedings".

Sec. 23 on the System of Diversion regulates as follows. ${ }^{47}$

"Children in conflict with the law shall undergo diversion programs without undergoing court proceedings subject to the conditions herein provided:

(a) Where the imposable penalty for the crime committee is not more than six (6) years imprisonment, the law enforcement officer or Punong Barangay with the assistance of the local social welfare and development officer or other members of the LCPC shall conduct mediation, family conferencing and conciliation and, where appropriate, adopt indigenous modes of conflict resolution in accordance with the best interest of the child with a view to accomplishing the objectives of restorative justice and the formulation of a diversion program. The child and his/her family shall be present in these activities.

\footnotetext{
45 Danrivanto Budhijanto, Hukum Telekomunikasi, Penyiaran \& Teknologi Informasi Regulasi \& Konvergensi, Bandung: Refika Aditama, 2010, p. 251.

46 Sec. 4 of the Philippines's Republic Act No. 9344 or known as an Act Establishing a Comprehensive Juvenile Justice and Welfare System.

47 Sec. 23 of the Philippines's Republic Act No. 9344 or known as an Act Establishing a Comprehensive Juvenile Justice and Welfare System.
} 
(b) In victimless crimes where the imposable penalty is not more than six (6) years imprisonment, the local social welfare and development officer shall meet with the child and his/her parents or guardians for the development of the appropriate diversion and rehabilitation program, in coordination with the BCPC;

(c) Where the imposable penalty for the crime committed exceeds six (6) years imprisonment, diversion measures may be resorted to only by the court."

The Local Councils for the Protection of Children and the Sangguniang Kabataan design and implement diversion program. It is regulated in Sec. 15 and 17 of the Republic Act No. 9344. Parents/guardians of children in conflict with the law are "jointly responsible for the responsibility of the child." ${ }^{48}$ Parents shall be responsible for damages unless they prove, in line with the judge's decision in court, that they exercised reasonable supervision of the child at the time the child committed the offense and took reasonable and diligence efforts to prevent or discourage the child from committing the offense. The Republic Act No. 9344 as amended by R.A. 10630 deals with the civil liability of children in connection with diversion processes. ${ }^{49}$

Sec. 31 states that diversion programs should include adequate socio-cultural and psychological responses and services for children. Diversion programs should be carried out and are agreed upon by the parties. At the Punong Barangay level, diversion programs that can also be carried out are property restitution, repairs to the damage caused by the perpetrator, apologies either in writing or verbally, care, guidance and supervision orders, counseling for children in conflict with the law and his family, perpetrator's participation in training, seminars and lectures on anger management skills, problem solving and/or conflict resolution skills, value formation, and other skills that will assist the child in dealing with situations that could lead to repeat offenses. Other programs that can be carried out are participation in available community-based programs, including community service, or participation in education, as well as vocational and life skills programs. Diversion may be completed with confiscation of proceeds or instruments of crime, payment of court fees, or institutional care and custody.

In a case involving a child who is in conflict with the law, the victim has the right to be given information about the availability of restitution from the Ministry of Justice. It is regulated in the Rep. Act No. 7309 (1992).$^{50}$ According to a study by the UNICEF in the Philippines, when parents are unable to pay restitution to the victim,

48 See Sec. 15 and 17 of the Philippines's Republic Act No. 9344 or known as an Act Establishing a Comprehensive Juvenile Justice and Welfare System.

Danrivanto Budhijanto, op.cit., p. 99.

50 University of Minnesota, Revised Rule on Children in Conflict with the Law, http://hrlibrary.umn.edu/research/Philippines/rule_on_children.html, accesed on August 2020. 
the parents can substitute the form of restitution to the victim. UNICEF states as follows.

"In actual practice, parents/guardians are held responsible for compensating the victim(s) of their child's offence. Because many parents/guardians in the Philippines are unemployed and cannot pay the $c$ restitution to the victim(s), it is often agreed that the financial restitution may be paid in instalments. Sometimes the victim(s) absolves the parents/guardians from paying the remaining restitution after they have paid a certain number of instalments. Symbolic restitution is also applied. There was a case in which the mother agreed to work for the victim(s), i.e., washing the clothes of the victim(s) for a certain number of days. It also happens that the diversion facilitator makes the child responsible for financially and/or symbolically compensating the victim(s)". ${ }^{51}$

Parents/guardians of perpetrators are responsible to provide restitution to victims. Parents/guardians in the Philippines who have no job and unable to pay restitution to the victims, can pay in instalments. In practice, there were also parents who were willing to work for the victim, namely washing the victim's clothes for a certain number of days. Traditionally, children are treated as the responsibility of their parents or guardians. Adults make decisions in the best interests of the children and the state enforces their right to do so. The best interests of children also demand that children have the right to be heard from their opinions. This does not mean that the child has the right to make all decisions but rather that the children should be given the right to participate in discussions if it is relevant. ${ }^{52}$

Settlement of juvenile cases through diversion is also known in the Thai legal system. Many elements of restorative justice remain in the traditional ways of communal justice in some rural areas. With a strong background in Thai culture and the increasing problems resulting from the weaknesses of conventional criminal justice, it is not surprising to see the growing interest of restorative justice in Thailand. Formally, the first national seminar on restorative justice was held on January 6, 2002. The seminar officially introduced restorative justice to the Thai criminal justice community. The idea of restorative justice is called Samarn-Chan in Thai, which means social harmony, or Yutithum Samarn Chan, which means justice

51 United Nation Children's Fund “UNICEF”, "Diversion not Detention: A Study on Diversion and Other Alternative Measures for Children in Conflict with the Law in East Asia and the Pacific", Bangkok: UNICEF East Asia and the Pacific Regional Office (EAPRO), 2017, p. 99.

52 Rhona K.M Smith., (et.al), Hukum Hak Asasi Manusia, Yogyakarta: Pusat Studi Hak Asasi Universitas Islam Indonesia (PUSHAM UII), 2010, pp. 143-144. 
for social harmony. The media and society, as well as academicians, receive the terms well. ${ }^{53}$

A diversion agreement can take the form of restitution. Boonsit formulates various forms of restitution and benefits for victims as follows.

"Restitution can mean more than paying money to the victim, and it includes an apology from the offender to the victim and annex plan action of the cause of his offence. The offender will listen to the victim's feelings and the impact that the victim felt from the offender's action. This can be therapeutic for the victim to express his/her feelings and make an invisible impact on the offender. All this leads the offender to compensate/make reparations to the victim. It helps the offender to prepare himself to return to live in the community. The reparation will take the form of: (1) monetary restitution (2) doing some work for the victim (3) working for a community where the victim is the person who can choose what job to do (4) participating in rehabilitation activities such as drug rehabilitation or attending a counselling course or (5) the last choice is to do all of the above". ${ }^{54}$

Diversion is carried out to reduce the number of cases in court. ${ }^{55}$ Zalewski and Păroşanu explain that, at the court level, the Family Court can impose restitution measures on the perpetrator. For example, there can be an obligation to repair damage or perform certain services for the benefit of the victim or the community. There have been $92.5 \%$ of the 145 children in conflict with the law who participated in mediation and reached a mutual agreement through the mediation process. Financial restitution covers $57.8 \%$ of the agreements. One third asked for an apology and $10 \%$ required the offenders to provide services or work to the victims. $^{56}$

The settlements of juvenile cases outside the court, which are regulated in the juvenile justice system in Indonesia, the Philippines, and Thailand, originate from traditional culture and local wisdom. The idea of diversion also comes from the

53 Kittayarak, Kittipong, "Restorative Justice: The Thai Experience", Paper Presented at the $123^{\text {rd }}$ UNAFEI International Seminar on Victim Rights Protection and Restorative Justice Approach, Fuchu, Japan, 2003.

54 Boonsit, Angkana, "Restorative Justice for Adults and Juveniles in Thailand", Resource Material Series No. 93, $156^{\text {th }}$ International Senior Seminar Participants' Papers, 2014, p. 135.

55 Somjai Kesornsiricharoen, "The Role and Function of Public Prosecutors in Thailand", https://www.unafei.or.jp/publications/pdf/RS_No53/No53_28PA_Kesornsiricharoen.pdf, accessed on August 2020.

56 Wojciech Zalewski and Andrea Păroşanu, "European Research on Restorative Juvenile Justice, Volume I, Research and Selection of the Most Effective Juvenile Restorative Justice Practices in Europe: Snapshots from 28 EU Member States", International Juvenile Justice Observatory Brussels, 2015, p. 133, http://www.ejjc.org/sites/default/files/volume_i_-_snapshots_from_28_eu_member_states.pdf, accessed on August 2020. 
government's efforts to reduce cases in courtroom due to the limitations of correctional institutions. The form of restitution in the legal system for juvenile justice in Indonesia is still limited to payments in the form of money. On the other hand, restitution in the Philippines and Thailand is extended to social services. Such forms of restitution can be adopted in the concept of restitution in Indonesia. However, the reformulation of restitution by services must be regulated in a limitative manner and supervised by law enforcers to avoid slavery.

\section{E. Conclusion}

Juvenile's cases can be resolved deliberately through diversion involving the child and parents/guardians, the victims and/or their parents/guardians, community counselors, and professional social workers based on a restorative justice approach. The result of a diversion agreement can be in the form of a settlement with restitution. The Law number 11 of 2012 on the Criminal Justice System for Children mention the payment of restitution. Restitution for children who are victims of crime acts can be compensation for loss of wealth, compensation for suffering because of a criminal act, and/or reimbursement of medical and/or psychological treatment costs. Based on the provisions, the restitution is in the form of money. The laws and regulations in Indonesia do not regulate other forms of restitution. This condition causes children who come from poor families have less opportunity to settle their cases outside the court. This condition is different from the forms of restitution in the Philippines and Thailand. The two states have expanded the meaning of restitution by providing another option. It can be services performed by the perpetrator and/or the perpetrator's family to the victim and/or the victim's family, as well as repairing the damage caused by the perpetrator. This form of restitution is an alternative reformulation in the dimension of ius constituendum. However, law enforcers must determine and supervise the services form of restitution to avoid slavery.

\section{References}

\section{Books}

Abintoro, Pembaruan Sistem Peradilan Pidana Anak, Laksbang Grafika, Yogyakarta, 2012.

Barda Nawawi Arief, Beberapa Aspek Kebijakan Penegakan dan Pengembangan Hukum Pidana, Citra Aditya Bakti, Bandung, 1998.

Dahlan Thaib, Jazim Hamidi and Ni'matul Huda, Teori dan Hukum Konstitusi, Raja Grafindo Persada, Jakarta, 2009.

Danrivanto Budhijanto, Hukum Telekomunikasi, Penyiaran \& Teknologi Informasi Regulasi \& Konvergensi, Refika Aditama, Bandung, 2010.

Ds Dewi and Fatahillah A. Syukur, Mediasi Penal, Penerapan Restoratif Justice di Pengadilan Anak Indonesia, Indie Publishing, Depok, 2011. 
Rogers, Edwina, Diversion Programs in America's Criminal Justice System: A Report by the Center for Prison Reform, The Center for Prison Reform, Washington, DC, 2015.

O.C. Kaligis, Perlindungan Hukum atas Hak Asasi Tersangka Terdakwa dan Terpidana, Alumni, Bandung, 2006.

Lilik Mulyadi, Wajah Sistem Peradilan Pidana Anak Indonesia, PT. Alumni, Bandung, 2014.

Majda El Muhtaj, Dimensi-dimensi HAM Mengurai Hak Ekonomi, Sosial dan Budaya, Raja Grafindo Persada, Jakarta, 2009.

Moch. Faisal, Hukum Acara Pidana dalam Teori dan Praktek, Manda Maju, Bandung, 2001.

Muhammad Joni, Aspek Hukum Perlindungan Anak dalam Perspektif Konvensi Hak Anak, Citra Aditya Bakti, Bandung, 1999.

Pangestika Rizki Utami, Konsep Diversi dan Restorative Justice Sebagai Pergeseran Tanggung Jawab Pidana Pada Sistem Peradilan Pidana Anak, IAIN Purwokerto, Purwokerto, 2018.

Rhona K.M. Smith, (et.al), Hukum Hak Asasi Manusia, Pusat Studi Hak Asasi Universitas Islam Indonesia (PUSHAM UII), Yogyakarta, 2010.

Romli Atmasasmita, Teori \& Kapita Selekta Kriminolog, PT. Eresco, Bandung, 1992.

Slamet Muljana, Perundang-undangan Majapahit, Bhratara, Jakarta, 1967.

Sudarto, Kapita Selekta Hukum Pidana, Penerbit Alumni, Bandung, 1981.

Wagiati Sutedjo, Hukum Pidana Anak, PT Refika Aditama, Bandung, 2010.

\section{Other Documents}

Boonsit, Angkana "Restorative Justice for Adults and Juveniles in Thailand", Resource Material Series No. 93, $156^{\text {th }}$ International Senior Seminar Participants' Papers, 2014.

Ansori, "Perlindungan Hukum Terhadap Korban Perkosaan dalam Peradilan Pidana di Indonesia", Dissertation, Universitas Brawijaya, Malang, 2011.

Apong Herlina, (et.al), Perlindungan Terhadap Anak Yang Berhadapan Dengan Hukum, Manual Pelatihan Untuk Polisi, POLRI - UNICEF, Jakarta, 2004.

Chlmlinger, D., "Police Action and the Prevention of Juvenile Deliquency", in A. Borowski and JM. Murray (eds.), Juvenile Delinquency in Australia, Methuen Australia, New South Wales, 1985.

Dzhansarayeva, (et.al), "Problems of Formation of the Concept of Criminal Policy of State in the Theory of Criminal Law", Middle-East Journal of Scientific Research, Vol. 14, No. 4, 2013.

Fetri AR. Tarigan, "Upaya Diversi Bagi Anak dalam Proses Peradilan", Lex Crimen, Vol. 4, No. 5, 2015.

Fifid Bramita, and Irma Cahyaningtyas, "Children Hearing System sebagai Ide Pembaharuan Sistem Peradilan Pidana Anak di Indonesia", Jurnal Magister Hukum Udayana (Udayana Master Law Journal), Vol. 7, No. 4, 2018. 
Folk, Kenneht, "Early Intervention: Diversion and Youth Conferencing, A National Review of Current Approach to Diverting Juvenile from The Criminal Justice System", Government Attorney-General's Departement, Commonwealth of Australia, Australia, 2003.

Friendly Juin Umpele, "Analisis Yuridis Pertimbangan Hakim Dalam Penjatuhan Pidana Terhadap Anak Sebagai Pelaku Tindak Pidana Narkoba", Lex Crimen, Vol. 8, No. 2, 2019.

Hamka Muchtar, and Benny Diktus Yusman, "Implementasi Restorative Justice Dalam Penyelesaian Perkara Delinkuensi", Tadulako Master Law Journal, Vol. 4, No. 2, 2020.

Miszuarty Putri, "Pelaksanaan Restitusi Bagi Anak Yang Menjadi Korban Tindak Pidana Sebagai Bentuk Pembaruan Hukum Pidana Berdasarkan Peraturan Pemerintah Nomor 43 Tahun 2017", Soumatera Law Review, Vol. 2, No. 1, 2019.

Nurini Aprilianda, Laporan Akhir Pengkajian Hukum Tentang Model Pembinaan Anak Berbasis Pendidikan Layak Anak Dalam Sistem Pemasyarakatan, Pusat Penelitian dan Pengembangan Sistem Hukum Nasional Badan Pembinaan Hukum Nasional Kementerian Hukum dan Hak Asasi Manusia RI 2014.

Pedoman Perlindungan Anak, "Direktorat Bina Kesejahteraan Anak, Keluarga dan Lanjut Usia", Departemen Sosial, Jakarta, 2016.

Rina Nurhaliza, Herry Liyus, and Dheny Wahyudi, "Pelaksanaan Kesepakatan Diversi Pada Tingkat Penyidikan Dalam Sistem Peradilan Anak", Pampas: Journal of Criminal Law Vol. 1, No. 1, 2020.

Rr Putri A Priamsari, "Mencari Hukum Yang Berkeadilan Bagi Anak Melalui Diversi", Jurnal Law Reform, Vol. 14, No. 2, 2018.

Sekhroni, "Criminal Liability dan Diversi Terhadap Tindak Pidana Anak dalam Sistem Peradilan Anak di Indonesia", Unifikasi: Jurnal Ilmu Hukum Vol. 3, No. 1, 2016.

Kesornsiricharoen, Somjai, "The Role and Function of Public Prosecutors in Thailand",https://www.unafei.or.jp/publications/pdf/RS_No53/No53_28PA_Ke sornsiricharoen.pdf, accessed on August 2020.

University of Minnesota, "Revised Rule on Children in Conflict with the Law", http://hrlibrary.umn.edu/research/Philippines/rule_on_children.html., accessed on August 2020.

Kittayarak, Kittipong, "Restorative Justice: The Thai Experience", A presentation at the $123^{\text {rd }}$ UNAFEI International Seminar on Victim Rights Protection and Restorative Justice Approach, Fuchu, Japan, 2003.

United Nation Children's Fund, "Diversion not Detention: A study on diversion and other alternative measures for children in conflict with the law in East Asia and the Pacific", UNICEF East Asia and the Pacific Regional Office (EAPRO), Bangkok, 2017.

Zalewski, Wojciech and Andrea Păroşanu, "European Research on Restorative Juvenile Justice Volume I, Research and Selection of the Most Effective Juvenile 
Restorative Justice Practices in Europe: Snapshots from 28 EU Member States", International Juvenile Justice Observatory Brussels, 2015.

\section{Legal Documents}

The Universal Declaration of Human Rights.

The Beijing Rules.

The ECOSOC Res. 2000/14, U.N. Doc. E/2000/INF/2/Add.2 at 35 (2000).

Law Number 11 of 2012 on the Juvenile Criminal Justice System [Undang-Undang Republik Indonesia Nomor 11 Tahun 2012 tentang Sistem Peradilan Pidana Anak].

Government Regulation Number 43 of 2017 on the Implementation of Restitution for Children Who Are Victims of Crime [Peraturan Pemerintah Republik Indonesia Nomor 43 Tahun 2017 Tentang Pelaksanaan Restitusi Bagi Anak Yang Menjadi Korban Tindak Pidana].

Government Regulation Number 65 of 2015 on the Guidelines for the Implementation of Diversion and Handling of Children Aged Under 12 (Twelve) Years Old [Peraturan Pemerintah Republik Indonesia Nomor 65 Tahun 2015 tentang Pedoman Pelaksanaan Diversi dan Penanganan Anak Yang Belum Berumur 12 (Dua Belas) Tahun].

The Principal Punishment In The Form of Restitution or Panglisyawa or Patukusyawa.

The Republic of Philippine's Act No. 9344 or known as an Act Establishing a Comprehensive Juvenile Justice and Welfare System. 